\title{
Mapping Vulnerability of Cotton to Climate Change in West Africa: Challenges for Sustainable Development
}

\author{
Mary Ann Cunningham *D, Nicholas S. Wright (D), Penelope B. Mort Ranta, Hannah K. Benton, Hassan G. Ragy, \\ Christopher J. Edington and Chloe A. Kellner
}

Department of Earth Science and Geography, Vassar College, Poughkeepsie, NY 12604, USA; nwright@vassar.edu (N.S.W.); pmortranta@vassar.edu (P.B.M.R.); hbenton@vassar.edu (H.K.B.); hragy@vassar.edu (H.G.R.); cedington@vassar.edu (C.J.E.); ckellner@vassar.edu (C.A.K.)

* Correspondence: macunningham@vassar.edu

Citation: Cunningham, M.A.; Wright, N.S.; Mort Ranta, P.B.; Benton, H.K.; Ragy, H.G.; Edington, C.J.; Kellner, C.A. Mapping Vulnerability of Cotton to Climate Change in West Africa: Challenges for Sustainable Development. Climate 2021, 9, 68. https://doi.org/10.3390/cli9040068

Received: 27 March 2021

Accepted: 16 April 2021

Published: 19 April 2021

Publisher's Note: MDPI stays neutral with regard to jurisdictional claims in published maps and institutional affiliations.

Copyright: (c) 2021 by the authors. Licensee MDPI, Basel, Switzerland. This article is an open access article distributed under the terms and conditions of the Creative Commons Attribution (CC BY) license (https:// creativecommons.org/licenses/by/ $4.0 /)$.

\begin{abstract}
Climate models project vulnerability to global warming in low-income regions, with important implications for sustainable development. While food crops are the priority, smallholder cash crops support food security, education, and other priorities. Despite its importance as a populous region subject to substantial climate change, West Africa has received relatively slight attention in spatial assessments of climate impacts. In this region, rainfed cotton (Gossypium hirsutum) provides essential smallholder income. We used a spatially explicit species distribution model to project likely changes in the spatial distribution of suitable climates for rainfed cotton in West Africa. We modeled suitable climate conditions from the recent past (1970-2000) and projected the range of those conditions in 2050 (Representative Concentration Pathways (RCP) 4.5 and 8.5). The suitable area declined by 60 percent under RCP4.5 and by 80 percent under RCP8.5. Of 15 countries in the study area, all but two declined to less than ten percent suitable under RCP8.5. The annual precipitation was the most influential factor in explaining baseline cotton distribution, but 2050 temperatures appear to become the limiting factor, rising beyond the range in which rainfed cotton has historically been grown. Adaptation to these changes and progress on sustainable development goals will depend on responses at multiple scales of governance, including global support and cooperation.
\end{abstract}

Keywords: climate impacts; rainfed cotton; species distribution model (SDM); Maxent; sustainable development goals (SDGs); West Africa

\section{Introduction}

\subsection{Climate Change and Sustainable Development in West Africa}

Climate change poses clear risks for agrarian communities in West Africa, steepening the already urgent challenges of sustainable development [1-3]. In the context of UN Sustainable Development Goals (SDGs), regional development organizations have identified climate-smart and sustainable farming practices such as high yielding and heat tolerant varieties, conservation agriculture, and agroforestry as key priorities [3-6]. Climate adaptation in agriculture is urgent for multiple SDGs that involve nutrition and economic stability in rural communities [7].

In a context of SDG planning, West Africa is simultaneously the world's fastest growing region and a region where humanitarian development conditions will be strongly impacted by climate change [3]. The region has a large agrarian population, predominantly small-holders with modest access to capital, and the average temperatures are higher than in many agricultural regions [8]. Warming conditions and precipitation shifts are likely to have especially important impacts on livelihoods and on development efforts in this region-exacerbating conflict and political instability at larger scales. It is therefore important to understand how much change in climate suitability for crops can be expected, and how those changes are likely to be geographically distributed [3,9]. Spatially explicit 
models of climate impacts on crops are increasingly common, but few studies have applied them to future crop production in this region. Exceptions include the work of Jalloh et al. [10] which projected changes in maize, rice, and other key food crops, as well as Akpoti et al.'s [11] projection of changing rice production in Benin and Togo.

Cotton (Gossypium hirsutum) is an economic mainstay for smallholder farmers and for regional economies across West Africa [12]. Income from cotton production supports improved food security, health care, sanitation, and education, all critical aspects of sustainable development [13]. A decline in cotton production has multiple follow-on effects for the wellbeing of smallholder farmers [14]. Small farms, averaging less than 4 ha, produce most of the cotton in West Africa [12,15] and nearly all of the cotton here is rainfed, reflecting in part a lack of access to irrigation for low-income farmers. Understanding the geographic distribution of its vulnerability to climate change is critical for anticipating prospects and strategies for sustainable development in different parts of the region. Understanding changes in the distribution of suitable growing areas also provides insights into the prospects for the production of other crops in the region.

\subsection{Spatially Explicit Modeling of Climate Factors}

We used a species distribution model (SDM) approach to model the range of suitable climate conditions for rainfed cotton in West Africa. In general, SDMs model the suitable range for a species. The range can then be mapped onto future climate scenarios or other environmental changes $[16,17]$. For domesticated crops, many factors beyond environmental constraints control plant viability and productivity. For example, crop breeding [14], genetic technology [12,17,18], land management [19], and economic drivers [12,20] all factor into patterns of cotton production. Even so, an SDM approach has proven useful in projecting impacts of climate change for domestic crops, for example, rainfed cereals in Ethiopia, rainfed maize cultivation in Kenya [21], and rice production in Benin and Togo [11].

We used observed occurrences to model baseline conditions from the recent past (19702000), then projected the range of those conditions to 2050 based on two climate scenarios: RCP4.5, representing aggressive climate action, and RCP8.5, representing extreme change, and also business as usual [2]. This approach allowed us to identify the climatic factors that potentially affect the suitability for cotton production and to quantify changes in the range of rainfed cotton production.

A model of future conditions provides a hypothesis of the likely outcomes of current processes, not a definitive prediction [22]. Thus, there is always uncertainty in models, but given the importance of anticipating the difference in climate trajectories [23] a model such as this can provide a useful approximation to help inform adaptation strategies. Visualizing patterns of possible change can be useful, for example, in supporting initiatives to transition or diversify the economic options for the region's farmers.

\subsection{Cotton, Climate, and Smallholder Income}

As a globally traded commodity, cotton is critical not only for local economies but also for regional and national economies in West Africa [15,24]. For smallholder farmers, cotton is the most widespread cash crop (as well as an important dietary oilseed), and it is the second most valuable after cocoa, which grows only in reliably humid areas [12]. These smallholders make West Africa, as a region, the world's fifth-largest cotton producer and the third-largest exporter (after North America and Central Asia: [15]).

The crop is particularly important for the "Cotton Four" countries of Benin, Burkina Faso, Chad, and Mali, each of which depends heavily on cotton as an export commodity [20]. Due to cotton's significance, these countries have sought to stabilize global trade and to reduce subsidies in wealthy countries for cotton production $[18,20]$. These subsidies depress global cotton prices and undermine production in countries with less-developed economies [13,19], which is an important issue for national and regional economic stability. 
Although it originates at low latitudes and tolerates higher temperatures than many crops, cotton suffers heat shock from prolonged hot periods. Fertility declines in high temperatures: plant stress occurs above $35^{\circ} \mathrm{C}$; the ideal temperatures for boll production are $18{ }^{\circ} \mathrm{C}-32{ }^{\circ} \mathrm{C}$; and cool nights are needed for flowering [12,24]. Importantly, cotton can withstand some drought, making it suitable for semiarid regions [12].

Unlike drought sensitivity-which plant breeders can modify through traits such as plant size, growth form, or salt tolerance-sensitivity to high temperatures involves basic cell functions that are not readily modified through breeding $[25,26]$. Temperature sensitivity can be mitigated through irrigation, as plants can reduce heat through the transpiration of water, but it is not easily changed through breeding or genetic modification.

Nearly all cotton in West Africa is rainfed because the seasonally humid climate supports this production and because irrigation is unavailable to most of the region's producers. Water resources for irrigation are insufficient in most of the region, as are infrastructure and access to capital for subsistence farmers. Water resources in the region also support other critical resources, such as fisheries. Thus, in timing and abundance, the reliability of the seasonal rains is essential for cotton economies [27].

\section{Methods}

\subsection{Study Area}

Our study area encompassed the main area of West African cotton production, as represented by production data from Portmann et al. (2010, Figure 1). The southern extent of this region has a humid tropical climate with 1000-1500 mm of rainfall annually, and precipitation declines sharply toward the arid northern extent of the study area, which grades through savannah vegetation to arid steppe and desert conditions [28]. Annual mean temperatures range from approximately $22-30{ }^{\circ} \mathrm{C}$. All mapping was done with a sinusoidal equal area projection, to allow estimation of cropping area extent.

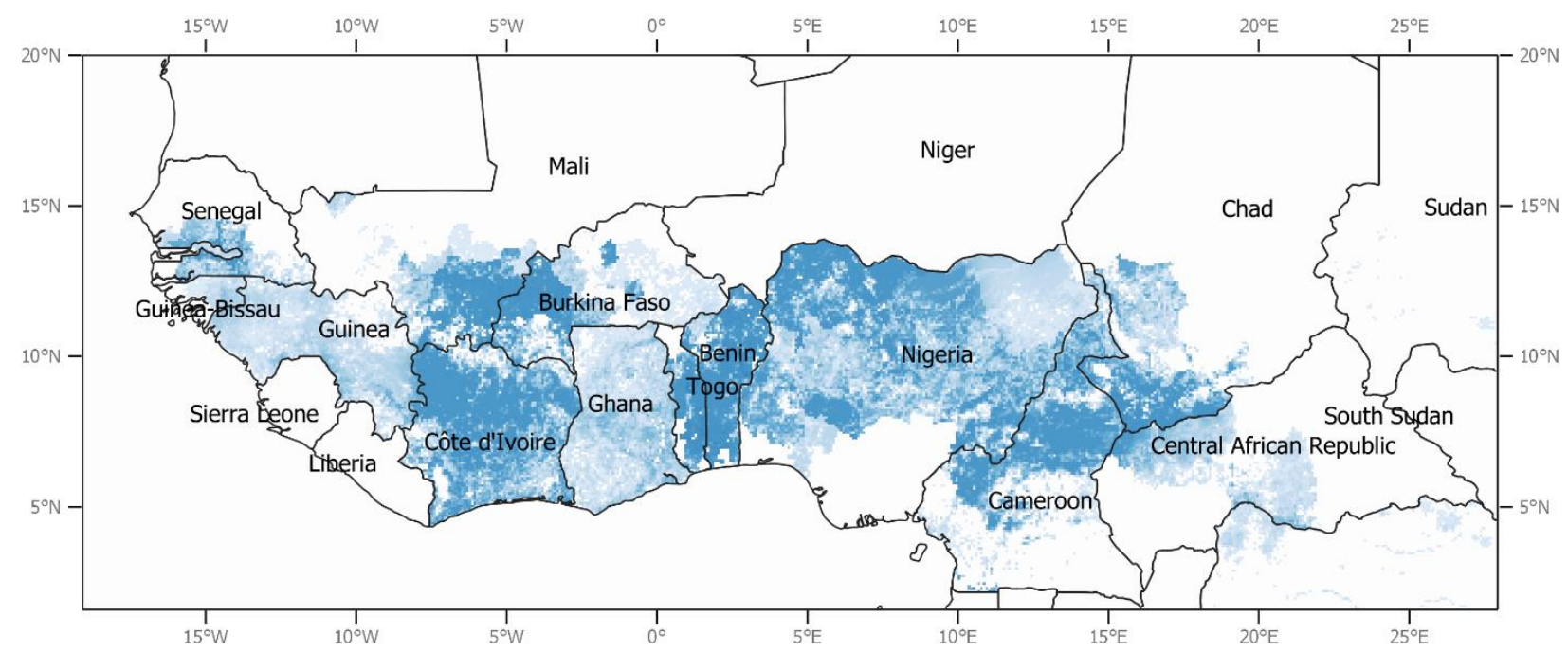

Rainfed cotton, area harvested (ha)

$\square 1 \square 10 \square 30 \square 50 \square 100 \square>100$

Figure 1. Study area, with distribution of rainfed cotton production in Africa, from MIRCA2000 data (using data from Portmann et al. 2010).

\subsection{Model Selection and Cotton Data}

Many model algorithms are available for species distribution modeling, and model output can vary according to multiple factors, such as choice of input climate variables, algorithm, or study area extent. To choose a model algorithm for use in this study, we 
conducted a preliminary comparison of models widely used in SDM studies in order to assess differences and to test whether one modeling approach provided better explanation than others. For this comparison, we ran a baseline model for rainfed cotton in the study region using six algorithms: artificial neural network (ANN), boosted regression tree (BRT), maximum entropy (Maxent), generalized additive model (GAM), generalized linear model (GLM), and multivariate adaptive regression splines (MARS; Table 1). These run on R and are widely available [29,30]. Test statistics generally used to compare algorithms include AUC (area under the receiver-operating characteristics curve) and true skills statistic (TSS). The AUC reports the relative rate of model sensitivity (the proportion of correctly predicted presences) and specificity (the proportion of correctly predicted random pseudoabsences). The TSS is calculated as (sensitivity + specificity - 1), as discussed by Allouche et al. [31]. We used these test statistics to select one "best" algorithm for use in modeling future (2050) climate conditions.

Table 1. SDM algorithms, with AUC and TSS statistics.

\begin{tabular}{|c|c|c|c|c|}
\hline Algorithm & Type & Abbreviation & AUC & TSS \\
\hline $\begin{array}{l}\text { Artificial neural } \\
\text { network }\end{array}$ & $\begin{array}{l}\text { machine } \\
\text { learning }\end{array}$ & ANN & 0.81 & 0.125 \\
\hline $\begin{array}{l}\text { Boosted } \\
\text { regression tree }\end{array}$ & $\begin{array}{l}\text { machine } \\
\text { learning }\end{array}$ & BRT & 0.74 & 0.274 \\
\hline $\begin{array}{l}\text { Maximum } \\
\text { entropy }\end{array}$ & $\begin{array}{l}\text { machine } \\
\text { learning }\end{array}$ & Maxent & 0.87 & 0.601 \\
\hline $\begin{array}{c}\text { Generalized } \\
\text { additive model }\end{array}$ & statistical model & GAM & 0.85 & 0.582 \\
\hline $\begin{array}{l}\text { Generalized } \\
\text { linar model }\end{array}$ & statistical model & GLM & 0.81 & 0.548 \\
\hline $\begin{array}{l}\text { Multiple } \\
\text { adaptive } \\
\text { regression spline }\end{array}$ & statistical model & MARS & 0.84 & 0.554 \\
\hline
\end{tabular}

Cotton presence points, used as input to models, were defined randomly within areas of rainfed cotton production, as derived from the Monthly Irrigated and Rainfed Crop Area around the year 2000 data set (MIRCA2000: [32], https: / / www.uni-frankfurt.de/45 218031/, accessed on 26 March 2021). The MIRCA2000 dataset derives from national and subnational agriculture census data and represents crop area harvested in 1998-2002 [32]. We focused our analysis on areas with concentrated production, following the approach of Evangelista et al. [33] and Singh et al. [34]. These areas of concentrated production included areas with more than 30 ha of cotton per cell (ranging from 30 to 1927 ha, or 0.34-22.7 percent of a cell). Within this concentrated area, we then generated 500 random points, with a minimum separation of $5 \mathrm{~km}$, to represent presence points within areas of relatively high production [33].

\subsection{Climate Data}

For baseline climate variables, we used bioclimatic variable layers at a resolution of 5 arc-minutes ([35,36]; https:/ / worldclim.org/data/bioclim.html, accessed on 26 March 2021). Bioclimatic layers represent seasonal characteristics, such as precipitation of the warmest quarter, eliminating the need to select monthly growing season variables, which are likely to differ across the study area. The baseline year range for this source represents a long-term average for 1970-2000.

For future climate projections, the Intergovernmental Panel on Climate Change (IPCC) has adopted a framework of representative concentration pathways (RCPs) that approximate the effects of different concentrations of greenhouse gases [37]. For example, RCP4.5 (a trajectory involving 4.5 Watts per $\mathrm{m}^{2}$ of radiative forcing) represents aggressive and coordinated climate action to stabilize emissions. In contrast, RCP8.5 (a trajectory with 8.5 Watts per $\mathrm{m} 2$ of radiative forcing) represents extreme warming [37]. Schwalm et al. [38] 
have noted that the current trajectory of carbon dioxide $\left(\mathrm{CO}_{2}\right)$ emissions is most consistent with RCP8.5. Future projections represent average conditions of a bioclimatic variable around the year 2050 (2040-2059). In this study, 2050 climate data layers were the same bioclimatic layers used in the baseline model, for RCP4.5 and RCP8.5, acquired 5-arc-minute resolution, from the Research Program on Climate Change, Agriculture, and Food Security (http:/ / www.ccafs-climate.org/data_spatial_downscaling/; accessed on 26 March 2021, Ramirez-Villegas and Jarvis 2010, [39,40]).

Different models of future climates vary in assumptions and projections, so we used an ensemble average of ten global circulation models (GCMs) to represent 2050 climate conditions, following de Sherbinin et al.'s [41] study of climate impacts in Mali (Table S1). For all 19 bioclimatic layers, averages of the ten climate models were used in analysis. For the most important of the bioclimatic variables, we also assessed agreement among the ten GCMs to assess how much they converged on similar projections of 2050 conditions (Figure S1).

\subsection{Climate Variable Selection and Comparison}

A subset of the 19 bioclimatic variables was selected for use in the SDMs. This selection process involved running a preliminary model (with Maxent) to assess which of the 19 bioclimatic variables provided the strongest discrimination of cotton occurrence points, then testing for multicollinearity among variables [11,21]. To evaluate multicollinearity, we followed the approach of Evangelista et al. [33]: we randomly generated 5000 points within the study area, sampled values of all 19 bioclimatic variables at those points, and then calculated correlation coefficients among variables at these points. Where correlation coefficients were greater than $|0.70|$ we excluded one of the pair, keeping the variable that had ranked higher in a preliminary model run using all 19 variables.

We compared the explanatory strength of input variables in isolation using a jackknife function, which calculates the strength of explanation with that variable only, excluding all others [42]. For the most important variables, we evaluated how individual bioclimatic variables influenced changes (from baseline years to 2050) in the distribution of suitable conditions: to do this, we identified climate ranges in which high-production cotton points occurred, then used those ranges to map areas that were more hot/dry, suitable, or more cool/wet in 2050 models (Figure S2a).

\subsection{Suitability Classification}

The SDM output reports environmental suitability in a continuous, unitless scale from 0 (unsuitable) to 1 (suitable). To compare the amount of suitable area from baseline to 2050, however, it is necessary to aggregate the continuous values into classes of "suitable" or "unsuitable" c.f. $[33,34]$. Seventy percent of cotton presence points occurred in areas with suitability values greater than 0.66 in our baseline suitability output. Another 25 percent fell in areas with suitability of $0.33-0.66$, and 5 percent were below 0.33 . We used these cutoffs, then, to classify continuous suitability values into three classes. Suitability values $>0.66$ characterized as "suitable;" values $0.33-0.66$ as marginally suitable, or "marginal." Suitability values $<0.33$ were designated as "unsuitable." Reducing suitability to three classes allowed us to calculate changes in the extent of suitable area among countries for baseline and the two 2050 scenarios. As a "suitable" value of 0.66 included 70 percent of baseline presence points, and a "marginal" threshold of 0.33 included all but 5 percent of presence points, these cutoffs are generous, rather than restrictive, in including potential cotton-growing areas.

We calculated the area in $\mathrm{km}^{2}$, and percentage change, for each of the three suitability ranges, for each country within the study area for baseline and 2050 projections.

\subsection{Comparison to Global Cotton-Growing Regions}

To compare the degree of climate change in West Africa to that in other world cotton regions, we compared the range of recent and future temperature conditions worldwide. 
We generated 500 random points within areas of concentrated production for rainfed cotton (>30 ha harvested per cell) for each of seven major world regions (Figure S3). For each point, we extracted values for the mean temperature of the warmest month (Bio 10) for baseline, 2050 RCP4.5, and 2050 RCP8.5.

\section{Results}

\subsection{Model and Variable Selection}

Among the six SDM algorithms, several had similar accuracy in predicting baseline presence and absences (Table 1). Mapped suitability was also similar for most algorithms (Figure S4). This similarity of accuracy and output suggested that multiple approaches could produce approximately similar conclusions. Among the algorithms, Maxent performed best both in AUC and TSS. We proceeded with Maxent for subsequent steps of analysis.

In the baseline Maxent model, variables providing the greatest amount of explanation were annual precipitation, precipitation of the warmest quarter, and temperature seasonality (standard deviation; Table 2). Two temperature variables, mean temperature of the warmest month (Bio 10) and mean temperature of the driest month (Bio 9) provided little explanation in the full model. Still their AUCs, calculated in the jackknife process for each variable in isolation, were strong (Figure S5). The individual AUC for Bio 10 alone was 0.71, only slightly lower than the individual AUC for the top variables (Table 2). The individual AUC for Bio 9 was 0.63.

Table 2. List of bioclimatic variables used in final Maxent model, and percentage contribution to Maxent model, listed in order of contribution. Individual AUC is the AUC from jackknife tests, using a model with the individual variable only.

\begin{tabular}{|c|c|c|c|}
\hline Variable & Definition, Units & $\begin{array}{c}\text { Percent } \\
\text { Contribution }\end{array}$ & Individual AUC \\
\hline Bio 12 & $\begin{array}{l}\text { Annual precipitation, } \\
\mathrm{mm}\end{array}$ & 57 & 0.79 \\
\hline Bio 4 & $\begin{array}{c}\text { Temperature } \\
\text { seasonality (std dev) }\end{array}$ & 21 & 0.77 \\
\hline Bio 18 & $\begin{array}{c}\text { Precipitation of } \\
\text { warmest quarter, } \mathrm{mm}\end{array}$ & 17.8 & 0.78 \\
\hline Bio 10 & $\begin{array}{l}\text { Mean temperature of } \\
\text { warmest quarter, }{ }^{\circ} \mathrm{C}\end{array}$ & 2.2 & 0.71 \\
\hline Bio 9 & $\begin{array}{l}\text { Mean temperature of } \\
\text { driest quarter, }{ }^{\circ} \mathrm{C}\end{array}$ & 2 & 0.63 \\
\hline
\end{tabular}

\subsection{Change in Suitable Area}

The mapped output indicated extensive "suitable" areas across the study region under baseline climate conditions (Figure 2, top). The extent of suitable areas declined for RCP4.5 (Figure. 2, middle), and RCP8.5 (Figure 2, bottom). Suitable conditions retreated in RCP8.5 to the center of the baseline range, principally in northern Nigeria and in the Central African Republic. 

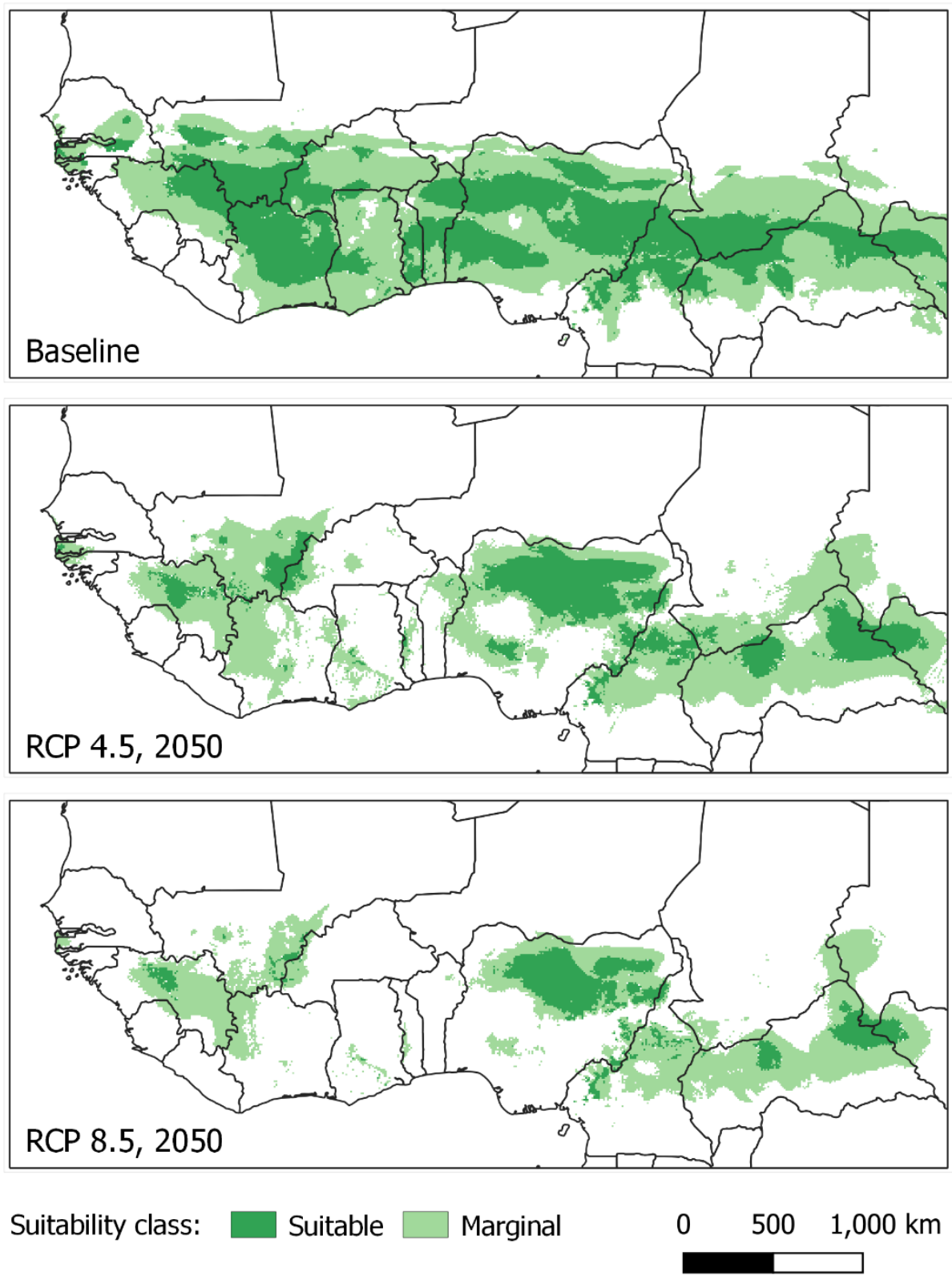

Figure 2. Suitability maps for baseline (top), RCP4.5 (middle), and RCP8.5 (bottom) climate conditions, using five bioclimatic variables. Areas shown as "suitable" represent suitability values of 0.67-1.0. "Marginal" areas represent suitability values of $0.33-0.66$.

For combined suitable and marginal area, Nigeria and the Central African Republic had the second largest area (Figure 3). Note that "marginal" areas contained only a quarter of presence points in baseline conditions. In both 2050 scenarios, the amount of marginal area increased for all countries, and the amount of suitable area declined or disappeared. Burkina Faso, Chad, and Cote d'Ivoire were among the countries losing the most suitable and marginal areas. 


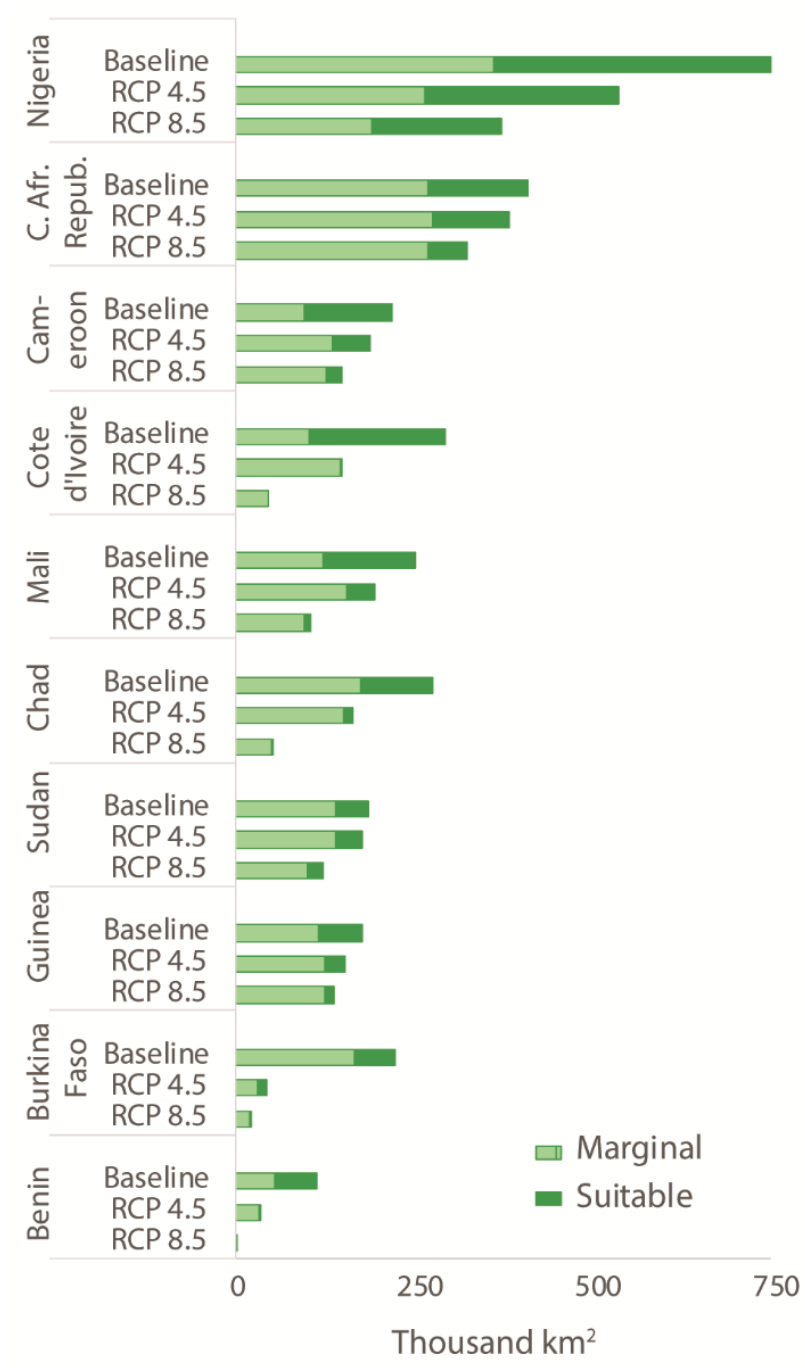

Figure 3. Extent of suitable area $\left(\mathrm{km}^{2}\right)$ by country, for the ten leading cotton producers in the study area. "Suitable" areas represent modelled suitability values of 0.67-1.0; "marginal" areas represent suitability values of $0.33-0.66$.

For most countries, the extent of suitable area under RCP4.5 was similar to that under RCP8.5. Under baseline conditions, Nigeria and Cote d'Ivoire had the greatest extent of suitable area (Figure 3), but of these two, Nigeria lost nearly half in the RCP8.5 scenario, and Cote d'Ivoire lost nearly all in both 2050 scenarios. Other countries for which cotton is economically very important, especially Burkina Faso, Chad, and Benin, lost most of their suitable cotton area under RCP4.5 and nearly all of it under RCP8.5. Benin and Chad also lost most of their marginal area.

In terms of percentage change, the losses were great in some of the four cottondependent countries (Table 3). Benin and Cote d'Ivoire had the greatest losses under both 2050 scenarios. Of the 15 countries with a substantial percentage of the area producing cotton, all but Nigeria appeared to lose over half under RCP4.5, and ten fell to below one percent under RCP8.5. Only Nigeria retained nearly half of the baseline percentage of area with a suitable climate. 
Table 3. Percentage of country area that was "suitable" for rainfed cotton, for baseline, RCP4.5, and RCP8.5 models, for 15 countries in the study area. Values show the percentage of each country that had suitability index values of 0.67 to 1.0 . Countries are sorted by percentage baseline suitability.

\begin{tabular}{cccc}
\hline Country & Baseline & RCP4.5 & RCP8.5 \\
\hline Côte d'Ivoire & 59.45 & 0.65 & 0.00 \\
Benin & 51.42 & 1.07 & 0.00 \\
Togo & 46.29 & 3.64 & 0.00 \\
Nigeria & 43.38 & 30.17 & 20.17 \\
South Sudan & 33.78 & 23.32 & 12.02 \\
Cameroon & 26.86 & 11.02 & 4.87 \\
Guinea & 24.56 & 11.13 & 5.57 \\
Central African & 22.99 & 17.30 & 9.03 \\
Republic & 21.11 & 5.04 & 0.67 \\
Burkina Faso & 19.53 & 0.00 & 0.00 \\
Gambia & 13.62 & 4.05 & 0.84 \\
Mali & 13.57 & 1.00 & 0.28 \\
Ghana & 9.20 & 1.15 & 0.01 \\
Chad & 6.45 & 0.67 & 0.00 \\
Senegal & 3.84 & 0.00 & 0.00 \\
Guinea-Bissau & & &
\end{tabular}

While precipitation variables largely explained the historical distribution of rainfed cotton, temperature variables evidently drove changes in future distributions (Figure 4). Annual precipitation (Bio 12) varied little from baseline years to 2050, but mean temperature of the driest quarter (Bio 9) changed dramatically in most of the region. Seasonal variation in temperatures, that is, contrast between extremes of hot and cool seasons (Bio 4), also varied little (Figure S2a,b). While this variable was important in explaining the past distribution of cotton, it appears unlikely to change as dramatically as the temperature in coming decades. For all bioclimatic variables, changes by 2050 were similar for RCP4.5 and $\mathrm{RCP} 8.5$ (Figure S2b,c), suggesting that even a less extreme degree of climate forcing is still likely to have serious impacts on growing conditions.

\subsection{Comparison to Global Production Regions}

To put this region in a context of other global rainfed cotton regions, we plotted global ranges of values for mean temperature of the warmest month (Bio 10) for baseline, RCP4.5, and RCP8.5 climate conditions (Figure 5). Seven major clusters of rainfed cotton that appear in MIRCA2000 crop production data are shown, with boxes showing median and quartile values. (For the designation of regions, see Figure S3). For all regions, median temperature values for RCP4.5 were closer to RCP8.5 than to baseline. This finding corresponds to similar results for West Africa alone in Table 3. Among these regions, West Africa was the second hottest cotton growing region for both RCP4.5 and RCP8.5. For RCP8.5, most temperatures exceed the range where cotton has historically been produced. 
Annual precipitation (Bio 12)
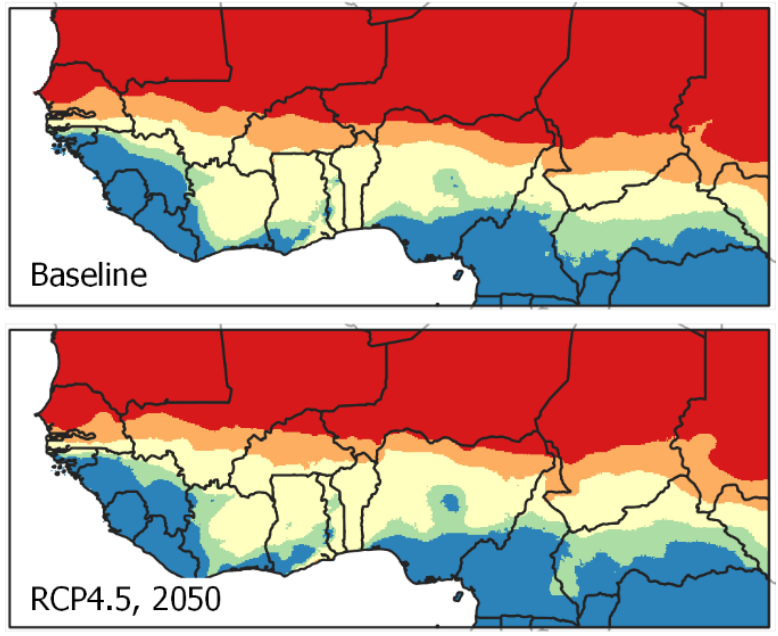

Mean temperature of driest quarter (Bio 9)
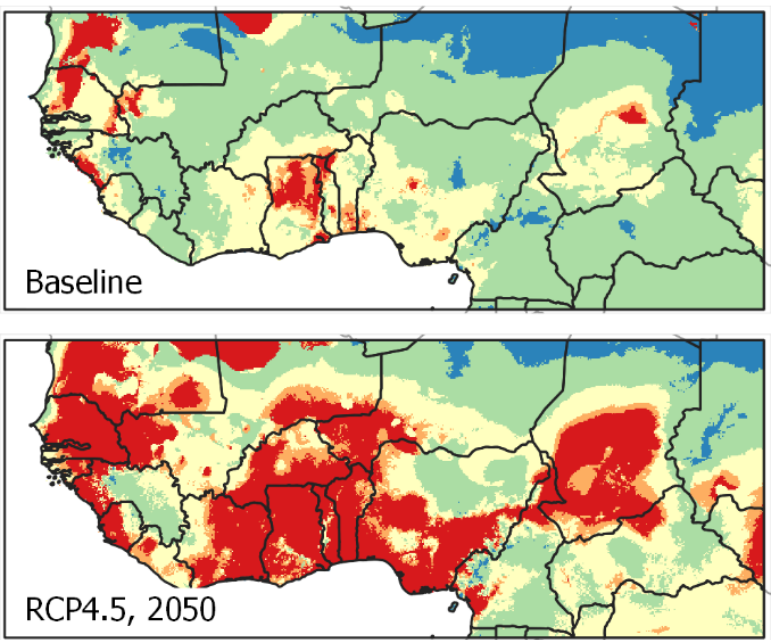

More wet or cool

Most suitable

More dry or hot

Figure 4. Change from baseline to 2050, RCP4.5, for annual precipitation (Bio 12) and mean temperature of driest quarter (Bio 9). The RCP4.5 scenario represents aggressive climate action. Yellow represents high likelihood of cotton presence, with a Cloglog likelihood greater than 0.7 (see Figure S2a). Green and orange represent lower likelihood ( $>0.5$ to 0.7 ). Red areas were drier (Bio 12) or hotter (Bio 9) than most observed locations of cotton production; blue areas were wetter (Bio 12) or cooler (Bio 9) than most cotton occurrence locations. 


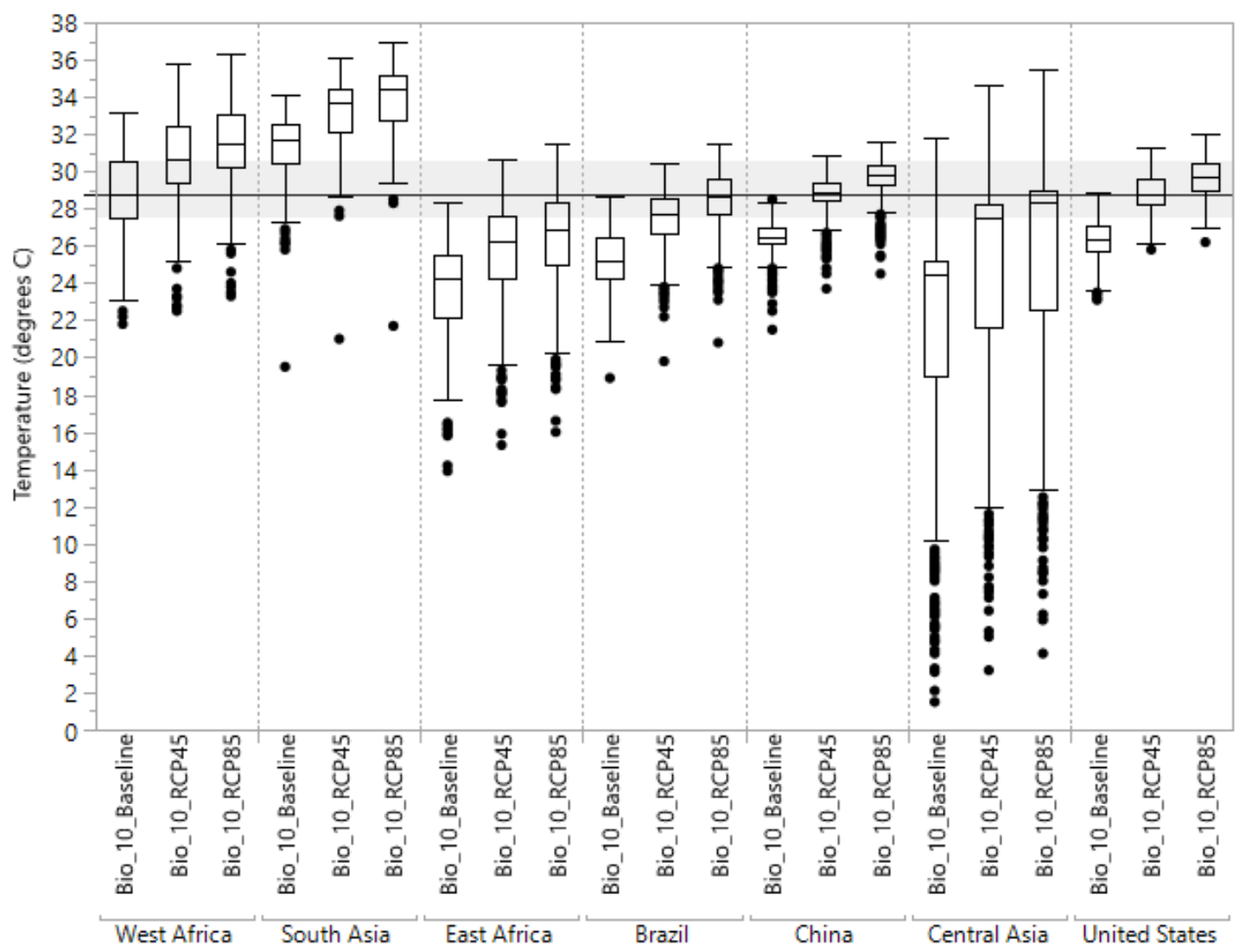

Figure 5. Global range of values for Bio 10 (mean temperature of warmest month), for baseline (Worldclim), RCP4.5, and RCP8.5 climate conditions. Seven major rainfed cotton regions represented in MIRCA2000 crop production data are shown (regions are shown in Figure S3). Boxplots show median, quartiles, deciles and outliers. Gray shading shows baseline interquartile range for West Africa.

\section{Discussion}

\subsection{Projected Changes and Sustainable Development Goals}

Our model output showed a declining extent of suitable climate conditions, but more notably, the extent of the suitable area projected for RCP4.5, with aggressive action to reduce the severity of warming, was more similar to RCP 8.5 conditions, extreme warming, than to baseline (Table 2). Our results suggest that by 2050 every country in West Africa is likely to experience a loss of land area suitable for cotton agriculture due to climate change. In total, among the 15 countries listed in Table 2, the model projected a decrease in suitable land by some 59 percent under RCP4.5 and 78 percent under RCP8.5. Even with aggressive climate action there will be an urgent need for humanitarian assistance and adaptation planning.

Losses were extreme in several cotton-growing countries. Côte d'Ivoire's suitable land dropped from almost 60 percent to 0 under RCP8.5. Benin, Mali, Burkina Faso, and Côte $\mathrm{d}$ 'Ivoire, all major producers in the region, may lose suitable areas. These changes are especially important for smallholder farms that depend on cotton for income, particularly in the Sahel [12]. For example, in Burkina Faso over two million Burkinabe citizens derived the majority of their income from cotton production, processing, or distribution in 2014 [12]. On a household scale, cotton cultivation has been linked to improved food production and nutrition, providing the credit needed to purchase agricultural inputs and equipment, benefiting food crops [43]. As such, exploring the implications of declining cotton suitability on rural communities and families is important for determining strategies for future adaptation. These changes are likely to have regional and multinational impacts if declining suitability accelerates rural to urban migration as farmers seek new livelihoods. 


\subsection{Model Selection and Uncertainty}

Although model output can depend on input parameters, algorithms, and other factors, agreement among our output of different algorithms suggests that confidence is warranted in regional patterns of change, and likely in the approximate magnitude of change. The output suitability maps for the different algorithms showed similar distributions of suitable conditions for the different algorithms. A combination of temperature and precipitation factors figured strongly in all of them. Among the SDM algorithms tested, Maxent provided the best prediction of cotton occurrence. Other studies have found similar species distributions $[11,21]$. The Maxent approach is thus widely used in various contexts [22,42-45]. However, similarity in output suggests that other algorithms could have yielded comparable conclusions about the trajectory of range shifts, when used for regional analysis.

A 2050 model is an hypothesis of likely change, not an observable outcome [22,33]. There are always risks associated with over-predicting environmental change [22], and models of 2050 climate conditions represent a 20-year average of climate variables, and as such they approximate general conditions, not precise conditions. That said, recent decades have shown model projections to be generally on track, if not conservative. Brysse et al. [46] have argued that models frequently have underpredicted observed climate changes and understated impacts. More recently, Oreskes et al. [47] found that projections of warming have been too low, and that recent changes have occurred faster than expected. Thus, while the changes mapped here remain untestable until 2050, there are strong reasons to consider these projections plausible.

\subsection{Changing Importance of Precipitation and Temperature}

One of the notable shifts between baseline and 2050 models was which variables appear most important in explaining cotton distribution. For baseline conditions, annual precipitation (Bio 12) was the most important bioclimatic variable, contributing over half of the explanation in our model. Temperature seasonality (Bio 4), a measure of the standard deviation of temperature, and precipitation of the warmest quarter (Bio 18) also discriminated presence points well. The importance of precipitation and temperature seasonality metrics reflects the stark difference between the arid, seasonally variable northern reaches of the study area and the equatorial, seasonally consistent southern reaches. Cotton suitability was the highest for all three of these variables at intermediate values, forming a highly productive east-west band across tropical West Africa (Figure 2, top).

By 2050, warming temperatures appear likely to become a limiting factor for production in the region. Increasing heat is a concern that has received considerable attention $[27,48,49]$, not in spatially explicit form. In the recent past (baseline conditions), the two seasonal temperature variables-mean temperature of the warmest quarter (Bio 10) and mean temperature of the driest quarter (Bio 9) — varied little across the study area and thus provided relatively little explanation in the baseline model. However, both temperature variables changed dramatically between the baseline and 2050, even under the moderate change of RCP4.5 (Figure 4, Figure S2b). While the distribution of cotton is has historically been limited by seasonal precipitation, then, significant warming may become a limiting factor in the coming decades.

Irrigation can reduce the effects of high temperatures, as plants can cool through transpiration when moisture is available, but irrigation resources are already limited in much of West Africa. Sylla et al. [49] found that although total annual rainfall is expected to remain consistent, precipitation may not support continued high cotton production, as rising temperatures increase potential evapotranspiration and reduce soil moisture and surface water. Options for increasing water storage for irrigation also are likely to be insufficient [49]. Much of this region is already warmer than other major cotton-producing regions, except South Asia (Figure 4). Future warming can be expected to exceed the range of most historical rainfed production. Anticipated warming, then, would likely cross unprecedented climate thresholds for this crop [50]. 
Precipitation, a key factor in rainfed cotton production, is an area of considerable uncertainty in climate projections [28,48,51]. This point is reflected in the disagreement we observed for bioclimatic variables representing precipitation (Figure S1). Uncertainty around future precipitation points to additional vulnerability for agrarian communities. The consistent timing and intensity of seasonal rainfall can be critical for crop production, and these may change in ways that climate models have been unable to predict with confidence. Inconsistent patterns or timing of rain between years or a transition towards less frequent but higher-intensity rainfall events could make the area less suitable for rainfed cotton production [51].

\subsection{SDGs and the Global Context of Adaptation}

Recent efforts have sought to support improved smallholder and fair trade cotton production [50,52], but if climate conditions are unlikely to support rainfed cotton in a few decades, and if irrigation resources remain limited, then more diverse strategies for sustainable development, more informed by climate model projections, appear important. Rather than investing in better cotton production, it may be important to focus on alternative strategies. Development goals for climate-smart agriculture initiatives for food production are well established. In addition to the fundamental need to protect nutritional resources, in this context, attention to income streams is important, if dependence on cotton becomes no longer viable.

Just as the drivers of climate warming are global, the responses require global and regional initiatives. The IPCC $[2,23]$ has emphasized that local, national, and global institutions can reduce risks to smallholders, and to national economies dependent on them, through increased technology sharing, improved transparency in governance, and increased financial support. The 2018 IPCC special report on $1.5^{\circ} \mathrm{C}$ of climate change [23], in particular, emphasized that international intervention can produce synergies, including poverty reduction and environmental quality, if strategies are chosen well. This report also noted the importance of innovating investment strategies, policy instruments, and technological innovations, at regional and international levels, to address the stability of agricultural communities [23]. International and institutional support will be vital for helping smallholder cotton farmers to adapt to changing conditions. Interventions could also exacerbate inequalities across many populations, if not chosen thoughtfully.

\section{Conclusions}

Although climate warming is well established in West Africa, the spatial of crop impacts across the region have received limited attention. This populous and growing region is extremely important as a world region that is likely to experience-and, indeed, is already experiencing - widespread humanitarian impacts of climate change. That said, paying attention to the spatial distribution of climate impacts can support remediation efforts. The geographical visualizations of trajectories are important for making future scenarios easier to perceive and can help support initiatives for change. Our findings suggest that even with concerted global action to reduce climate change, ideally to less than 1.5 degrees of warming, climate change is likely to have dramatic impacts on crop growing conditions in this region. Collaborative approaches to innovation, including empowering and amplifying knowledge at local scales, are essential to global goals for sustainable development.

Supplementary Materials: The following are available online at https://www.mdpi.com/article/ 10.3390/cli9040068/s1, Table S1: Model input, Figure S1: Model agreement, Figure S2, Method of designating optimal ranges for variables, Figure S3: Map of global cotton producing regions, Figure S4: Baseline suitability projections from five SDM algorithms, Figure S5: Jackknife results.

Author Contributions: Conceptualization, N.S.W., H.G.R., P.B.M.R., H.K.B., C.J.E., C.A.K., M.A.C.; methodology M.A.C., N.S.W., P.B.M.R., H.K.B., H.G.R., C.J.E., C.A.K.; analysis M.A.C., N.S.W., P.B.M.R., H.K.B., H.G.R., C.J.E., C.A.K.; writing-original draft preparation, M.A.C., N.S.W., P.B.M.R., 
H.K.B., H.G.R., C.J.E., C.A.K.; writing-review and editing, M.A.C., N.S.W., H.G.R.; visualization, M.A.C., N.S.W., P.B.M.R., H.K.B., H.G.R., C.J.E., C.A.K.; funding acquisition: C.A.K., C.J.E., H.G.R., project administration, M.A.C. All authors have read and agreed to the published version of the manuscript.

Funding: This research was supported by the Vassar College Environmental Research Institute, Collins Fund.

Acknowledgments: We express sincere thanks to L. Christenson, S. Tulowiecki, and F. Portmann for their generosity in reviewing this paper. We thank T. Stohlgren, A. Fent, and D. Pater for preliminary consultation on our work.

Conflicts of Interest: There are no known conflict of interest.

\section{References}

1. United Nations Development Programme (UNDP). Africa I UNDP Climate Change Adaptation. Available online: https://www. adaptation-undp.org/CCA-Africa (accessed on 10 April 2021).

2. $\quad$ Barros, R.V.; Field, C.B.; Dokken, D.J.; Mastrandrea, M.D.; Mach, K.J.; Bilir, T.E.; Ebi, K.L.; Estrada, Y.O.; Genova, R.C.; Girma, B.; et al. Climate Change 2014: Impacts, Adaptation, and Vulnerability; Cambridge University Press: Cambridge, UK; New York, NY, USA, 2014.

3. Chapman, S.; Birch, C.E.; Pope, E.; Sallu, S.; Bradshaw, C.; Davie, J.; Marsham, J.H. Impact of Climate Change on Crop Suitability in Sub-Saharan Africa in Parameterized and Convection-Permitting Regional Climate Models. Environ. Res. Lett. 2020, 15, 094086. [CrossRef]

4. Niang, I.; Ruppel, O.C.; Abdrabo, M.A.; Essel, A.; Lennard, C.; Padgham, J.; Urquhart, P. Africa. In Climate Change 2014: Impacts, Adaptation, and Vulnerability. Part B: Regional Aspects. Contribution of Working Group II to the Fifth Assessment Report of the Intergovernmental Panel on Climate Change; Cambridge University Press: Cambridge, UK; New York, NY, USA, 2014; pp. 1199-1265. Available online: https:/ / www.ipcc.ch/site/assets/uploads/2018/02/WGIIAR5-Chap22_FINAL.pdf (accessed on 10 April 2021).

5. ECOWAS. 2025 Strategic Policy Framework. (ECOWAS Department of Agriculture, Environment and Water Resources, Abuja, Nigeria). 2017. Available online: http://araa.org/sites/default/files/media/ECOWAP\%202025\%20Strategic\%20Policy\%20 Framework\%20ENG.pdf (accessed on 10 April 2021).

6. Sustainable Development Goals Center for Africa and Sustainable Development Solutions Network (SDGCA). Africa SDG Index and Dashboards Report 2020. Kigali and New York: SDG Center for Africa and Sustainable Development Solutions Network. 2020. Available online: https://sdgcafrica.org/wp-content/uploads/2020/10/2020_africa_index_and_dashboards.pdf (accessed on 10 April 2021).

7. UN Economic Commission for Africa (UNECA); United Nations. Economic Commission for Africa. Subregional Office West Africa (SRO-WA). Report on sustainable development goals for the West Africa subregion. Addis Ababa: UNECA. 2015. Available online: http:/ / hdl.handle.net/10855/22652 (accessed on 10 April 2021).

8. Dosio, A. Projection of Temperature and Heat Waves for Africa with an Ensemble of CORDEX Regional Climate Models. Clim. Dyn. 2017, 49, 493-519. [CrossRef]

9. Egbebiyi, T.S.; Crespo, O.; Lennard, C. Defining Crop-Climate Departure in West Africa: Improved Understanding of the Timing of Future Changes in Crop Suitability. Climate 2019, 7, 101. [CrossRef]

10. Jalloh, A.; Nelson, G.C.; Thomas, T.S.; Zougmoré, R.; Roy-Macauley, H. West African Agriculture and Climate Change: A Comprehensive Analysis; IFPRI Research Monograph; International Food Policy Research Institute: Washington, DC, USA, 2013. [CrossRef]

11. Akpoti, K.; Kabo-bah, A.T.; Dossou-Yovo, E.R.; Groen, T.A.; Zwart, S.J. Mapping Suitability for Rice Production in Inland Valley Landscapes in Benin and Togo Using Environmental Niche Modeling. Sci. Total Environ. 2020, 709, 136165. [CrossRef]

12. VIB Cotton in Africa. Ghent, Belgium: International Plant Biotechnology Outreach. 2017. Available online: https://ipbo.sites.vib. be/sites/ipbo.sites.vib.be/files/2021-01/Cotton\%20in\%20Africa.pdf (accessed on 10 April 2021).

13. Murphy, S.; Hansen-Kuhn, K. The Stubborn Persistence of U.S. Cotton Dumping. Institute for Agriculture and Trade Policy (IATP). 2017. Available online: https:/ / www.iatp.org/documents/stubborn-persistence-us-cotton-dumping (accessed on 10 April 2021).

14. Del Rio, A.; Simpson, B.M. Agricultural Adaptation to Climate Change in the Sahel: A Review of Fifteen Crops Cultivated in the Sahel; U.S. Agency for International Development (USAID): Washington, DC, USA, 2014. Available online: https:/ /www.climatelinks. org/resources/agricultural-adaptation-climate-change-sahel-review-fifteen-crops-cultivated-sahel (accessed on 10 April 2021).

15. OECD. Cotton: West Africa in the International Market. ECOWAS-SWAC/OECD: Atlas on Regional Integration in West Africa. 2006. Available online: https://www.oecd.org/swac/publications/38409410.pdf (accessed on 10 April 2021).

16. Prasad, A.M.; Iverson, L.R.; Matthews, S.; Peters, M. A Climate Change Atlas for 134 Forest Tree Species of the Eastern United States. 2007. Available online: https:/ / www.nrs.fs.fed.us/atlas/tree (accessed on 10 April 2021).

17. Young, N.E.; Fairchild, M.; Belcher, T.; Evangelista, P.; Verdone, C.J.; Stohlgren, T.J. Finding the Needle in the Haystack: Iterative Sampling and Modeling for Rare Taxa. J. Insect Conserv. 2019, 23, 589-595. [CrossRef] 
18. Vitale, J.; Vognan, G.; Vitale, P.P. The Socio-economic impacts of GM cotton in Burkina Faso: Does farm structure affect how benefits are distributed? AgBioForum 2016, 19, 120-135.

19. Mechiche-Alami, A.; Abdi, A.M. Agricultural Productivity in Relation to Climate and Cropland Management in West Africa. Sci. Rep. 2020, 10, 3393. [CrossRef] [PubMed]

20. Jales, M. How Would a WTO Agreement on Cotton Affect Importing and Exporting Countries? ICTSD Programme on Agricultural Trade and Sustainable Development Issue Paper No. 26; International Centre for Trade and Sustainable Development: Geneva, Switzerland, 2010.

21. Kogo, B.K.; Kumar, L.; Koech, R.; Kariyawasam, C.S. Modelling Climate Suitability for Rainfed Maize Cultivation in Kenya Using a Maximum Entropy (MaxENT) Approach. Agronomy 2019, 9, 727. [CrossRef]

22. Jarnevich, C.S.; Stohlgren, T.J.; Kumar, S.; Morisette, J.T.; Holcombe, T.R. Caveats for Correlative Species Distribution Modeling. Ecol. Inform. 2015, 29, 6-15. [CrossRef]

23. Intergovernmental Panel on Climate Change (IPCC). Summary for Policymakers. In Global Warming of $1.5^{\circ} \mathrm{C}$; Masson-Delmotte, V.P., Zhai, P., Pörtner, H.-O., Eds.; An IPCC Special Report on the Impacts of Global Warming of $1.5^{\circ} \mathrm{C}$ Above Pre-Industrial Levels and Related Global Greenhouse Gas Emission Pathways, in the Context of Strengthening the Global Response to the Threat of Climate Change, Sustainable Development, and Efforts to Eradicate Poverty; 2018; Available online: https: //www.ipcc.ch/sr15/chapter/spm/ (accessed on 10 April 2021).

24. Vitale, J. Economic Importance of Cotton in Burkina Faso. Background Paper to the UNCTAD-FAO Commodities and Development Report 2017 Commodity Markets, Economic Growth and Development. 2018. Available online: http://www.fao.org/3/i8 330en/I8330EN.pdf (accessed on 10 April 2021).

25. Burke, J.J.; Wanjura, D.F. Plant Responses to Temperature Extremes. In Physiology of Cotton; Stewart, J.M., Oosterhuis, D.M., Heitholt, J.J., Mauney, J.J., Eds.; Springer: New York, NY, USA, 2010; pp. 123-128.

26. Wells, R.; Stewart, A.M. Morphological alterations in response to management and environment. In Physiology of Cotton; Stewart, J.M., Oosterhuis, D.M., Heitholt, J.J., Mauney, J.R., Eds.; Springer: New York, NY, USA, 2010; pp. $24-32$.

27. Sylla, M.B.; Elguindi, N.; Giorgi, F.; Wisser, D. Projected Robust Shift of Climate Zones over West Africa in Response to Anthropogenic Climate Change for the Late 21st Century. Clim. Chang. 2016, 134, 241-253. [CrossRef]

28. Comité Permanent Inter-états de Lutte contre la Sécheresse dans le Sahel [CILSS]. Landscapes of West Africa-A Window on a Changing World; CILSS: Ouagadougou, Burkina Faso, 2016; 219p. [CrossRef]

29. Hijmans, R.J.; Elith, J. Spatial Distribution Modeling. 2019. Available online: https://rspatial.org/raster/sdm/SDM.pdf (accessed on 10 April 2021).

30. Hallgren, W.; Beaumont, L.; Bowness, A.; Chambers, L.; Graham, E.; Holewa, H.; Laffan, S.; Mackey, B.; Nix, H.; Price, J.; et al. The Biodiversity and Climate Change Virtual Laboratory: Where ecology meets big data. Environ. Model. Softw. 2016, 76, 182-186. [CrossRef]

31. Allouche, O.; Tsoar, A.; Kadmon, R. Assessing the Accuracy of Species Distribution Models: Prevalence, Kappa and the True Skill Statistic (TSS): Assessing the Accuracy of Distribution Models. J. Appl. Ecol. 2006, 43, 1223-1232. [CrossRef]

32. Portmann, F.T.; Siebert, S.; Döll, P. MIRCA2000-Global Monthly Irrigated and Rainfed Crop Areas around the Year 2000: A New High-Resolution Data Set for Agricultural and Hydrological Modeling: Monthly Irrigated and Rainfed Crop Areas. Glob. Biogeochem. Cycles 2010, 24. [CrossRef]

33. Evangelista, P.; Young, N.; Burnett, J. How Will Climate Change Spatially Affect Agriculture Production in Ethiopia? Case Studies of Important Cereal Crops. Clim. Chang. 2013, 119, 855-873. [CrossRef]

34. Singh, K.; McClean, C.J.; Büker, P.; Hartley, S.E.; Hill, J.K. Mapping Regional Risks from Climate Change for Rainfed Rice Cultivation in India. Agric. Syst. 2017, 156, 76-84. [CrossRef] [PubMed]

35. Hijmans, R.J.; Cameron, S.E.; Parra, J.L.; Jones, P.G.; Jarvis, A. Very High Resolution Interpolated Climate Surfaces for Global Land Areas. Int. J. Clim. 2005, 25, 1965-1978. [CrossRef]

36. Fick, S.E.; Hijmans, R.J. WorldClim 2: New $1 \mathrm{~km}$ spatial resolution climate surfaces for global land areas. Int. J. Clim. 2017, 37, 4302-4315. [CrossRef]

37. Intergovernmental Panel on Climate Change (IPCC). Summary for Policymakers. In Climate Change 2013: The Physical Science Basis; Contribution of Working Group I to the Fifth Assessment Report of the Intergovernmental Panel on Climate Change; Cambridge University Press: Cambridge, UK; New York, NY, USA, 2013.

38. Schwalm, C.R.; Glendon, S.; Duffy, P.B. RCP8.5 Tracks Cumulative $\mathrm{CO}_{2}$ Emissions. Proc. Natl. Acad. Sci. USA 2020, 117, 19656-19657. [CrossRef]

39. Ramírez Villegas, J.; Jarvis, A. Downscaling Global Circulation Model Outputs: The Delta Method Decision and Policy Analysis Working Paper No. 1; International Center for Tropical Agriculture. 2010. Available online: https://hdl.handle.net/10568/90731 (accessed on 10 April 2021).

40. Navarro-Racines, C.; Tarapues, J.; Thornton, P.; Jarvis, A.; Ramirez-Villegas, J. High-Resolution and Bias-Corrected CMIP5 Projections for Climate Change Impact Assessments. Sci. Data 2020, 7, 7. [CrossRef]

41. De Sherbinin, A.; Chai-Onn, T.; Giannini, A.; Jaiteh., M.; Levy, M.; Mara, V.; Pistolesi, L.; Trzaska, S. Mali Climate Vulnerability Mapping. USAID African and Latin American Resilience to Climate Change Project (ARCC). 2014. Available online: https:// www.usaid.gov/sites/default/ files/documents/1860/MALI\%20CLIMATE\%20VULNERABILITY\%20MAPPING.pdf (accessed on 10 April 2021). 
42. Phillips, S.J.; Anderson, R.P.; Schapire, R.E. Maximum Entropy Modeling of Species Geographic Distributions. Ecol. Model. 2006, 190, 231-259. [CrossRef]

43. Govereh, J.; Jayne, T.S. Effects of Cash Crop Production on Food Crop Productivity in Zimbabwe: Synergies or Trade-Offs? Food Security International Development Working Papers 54670; Michigan State University, Department of Agricultural, Food, and Resource Economics: East Lansing, MI, USA, 1999.

44. Merow, C.; Smith, M.J.; Silander, J.A. A Practical Guide to MaxEnt for Modeling Species' Distributions: What It Does, and Why Inputs and Settings Matter. Ecography 2013, 36, 1058-1069. [CrossRef]

45. Phillips, S.J.; Dudík, M.; Schapire, R.E. Maxent Software for Modeling Species Niches and Distributions (Version 3.4.1). Available online: http:/ /biodiversityinformatics.amnh.org/open_source/maxent/ (accessed on 10 April 2021).

46. Brysse, K.; Oreskes, N.; O’Reilly, J.; Oppenheimer, M. Climate Change Prediction: Erring on the Side of Least Drama? Glob. Environ. Chang. 2013, 23, 327-337. [CrossRef]

47. Oreskes, N.; Oppenheimer, M.; Jamieson, D. Scientists Have Been Underestimating the Pace of Climate Change. Scientific American Blog Observations. 2019. Available online: https://blogs.scientificamerican.com/observations/scientists-have-beenunderestimating-the-pace-of-climate-change/ (accessed on 10 April 2021).

48. United States Geological Survey (USGS). Climate I West Africa. Available online: https://eros.usgs.gov/westafrica/node/157 (accessed on 10 April 2021).

49. Sylla, M.B.; Pal, J.S.; Faye, A.; Dimobe, K.; Kunstmann, H. Climate Change to Severely Impact West African Basin Scale Irrigation in $2{ }^{\circ} \mathrm{C}$ and $1.5^{\circ} \mathrm{C}$ Global Warming Scenarios. Sci. Rep. 2018, 8, 14395. [CrossRef] [PubMed]

50. International Trade Centre (ITC). Cotton and Climate Change: Impacts and Options to Mitigate and Adapt; Technical paper, Doc. No. MAR-11-200.E; ITC: Geneva, Switzerland, 2011.

51. Adeniyi, M.O. The Consequences of the IPCC AR5 RCPs 4.5 and 8.5 Climate Change Scenarios on Precipitation in West Africa. Clim. Chang. 2016, 139, 245-263. [CrossRef]

52. United Nations Conference on Trade and Development (UNCTAD). Pan-African Cotton Road Map: A Continental Strategy to Strengthen Regional Cotton Value Chains for Poverty Reduction and Food Security; United Nations: Geneva, Switzerland, 2014. Available online: https://unctad.org/system/files/official-document/suc2014d6_en.pdf (accessed on 10 April 2021). 